\title{
О ПРИЧИНАХ ПОХОДА РУССКИХ КНЯЗЕЙ НА ПОЛОВЦЕВ В 1103 ГОДУ
}

\author{
A. А. Инков \\ (Московский гуманитарный университет)
}

Аннотация: Статья посвящена рассмотрению причин первого крупного похода русских князей против половцев в 1103 г.

Подготовлено на основе доклада автора на Всероссийской научной конференции «Военная история России», которая прошла в Московском гуманитарном университете 25 апреля 2016 г.

Ключевые слова: история России; половцы; Владимир Мономах; Святополк; история войн

\section{ON THE CAUSES OF THE CAMPAIGN OF RUSSIAN PRINCES AGAINST THE CUMANS IN THE YEAR 1103}

A. A. Inkov

(Moscow University for the Humanities)

Abstract: The article examines the causes of the first major campaign of the Russian princes against the Cumans in the year 1103.

This article is based on the paper presented at "The military history of Russia" conference, which was held at Moscow University for the Humanities on April 25, 2016.

Keywords: History of Russia; Cumans; Vladimir Monomakh; Sviatopolk; history of warfare

Поход объединенных русских дружин во главе с киевским князем Святополком Изяславичем и переяславским князем Владимиром Мономахом 1103 г. открывает период активных наступательных действий Руси против половцев, на протяжении всей второй половины XI - начала XII в. опустошавших своими набегами южное пограничье русских земель.

Поход был организован коалицией русских князей. Семь из них летописец называет поименно. Это - киевский князь Святополк Изяславич, переяславский князь Владимир Всеволодович Мономах, черниговский князь Давыд Святославич, сын Мономаха Ярополк Владимирович, возглавивший в походе отряды смоленцев, а также ряд более мелких правителей: племянник Святополка Киевского Вячеслав Ярополкович, Давыд 
Всеславич Полоцкий и Мстислав Давыдович, племянник волынского князя Давыда Игоревича (Повесть ..., 1950: 183). Во главе объединенного войска стояли киевский князь Святополк Изяславич и переяславский князь Владимир Мономах; последний был вдохновителем и фактическим руководителем похода (Перхавко, Сухарев, 2006: 79).

Начавшийся ранней весной поход русской рати был хорошо подготовлен как в организационном, так и в военно-тактическом плане. Подготавливая удар его, организаторы Владимир Мономах и Святополк Изяславич постарались максимально учесть особенности ведения войны с половцами в это время года. Для похода выбрано наиболее благоприятное время - начало весны. В рассматриваемое время после только что закончившейся бурной и снежной зимы кони половцев обычно сильно тощали и были неспособны нести на себе вооруженного всадника, а, следовательно, степная конница становилась небоеспособной и теряла свое главное преимущество на поле боя - высокую маневренность. Кроме того, как показало исследование Л. Н. Гумилева, в районе Днепра, вдоль которого наносился основной удар русских, зимой высота снежного покрова достигала не менее 40 см (Гумилев, 1994: 20). Поэтому половецкие орды с их огромными стадами не могли быстро откочевать при приближении русских вглубь своих степей и неизбежно должны были попасть под их удар. Учитывали русские князья и то, что во время похода они должны были иметь дело не столько с вооруженными отрядами половцев, сколько в первую очередь с мирным населением степи (Мургулия, Шушарин, 1998: 68), которое, скованное вежами и стадами, должно было стать их легкой добычей.

Одновременно хорошо продуман был и маршрут похода. Основные военные действия планировалось вести вдоль Днепра и в его низовьях. Весной здесь в преддверии скорой рыбной путины скапливалось большое количество половецких зимовищ; следовательно, в случае успеха половцам должны были быть нанесены максимальные потери.

Местом сбора выступивших из разных русских земель отрядов князей был выбран Переяславль, столица Переяславского княжества. Отсюда, объединенные полки в конце марта выступили в степь и пошли на юг двумя колонами: пехота в ладьях, а конница - вдоль левого берега Днепра. Добравшись до острова Хортица ${ }^{1}$, пешая рать вышла из ладей на берег и соединилась с конницей. Оставив корабли, русичи повернули на юговосток и углубились в половецкие степи. Через четыре дня они вышли к реке Сутень (по К. В. Кудряшову, совр. р. Молочная, впадающая в Азовское

${ }^{1}$ Существует предположение, что по дороге к Хортице русские могли громить припозднившиеся зимники половцев, которые располагались вдоль Днепра, прежде всего в районе днепровских порогов (Плетнева, 1992: 468). 
море, см.: Кудряшов, 1948: 91-95). По ее берегам располагались зимние становища орды лукоморских половцев во главе с ханом Урусобой - главный объект удара русских.

Узнав о приближении русских, половецкие ханы собрались на совет. Престарелый и опытный хан Урусоба - глава орды лукоморских половцев - предложил собравшимся отправить послов к русским и добиваться заключения мира. Однако младшие половецкие князья отвергли этот благоразумный совет и настаивали на сражении, рассчитывая одолеть в нем русских и затем самим уже напасть на оставшиеся беззащитными русские города. Это мнение и возобладало на совете. Половецкие ханы решели собрать войско и дать русским битву. Не дожидаясь пока соберутся главные силы, молодой половецкий хан Алтунопа с передовым отрядом выступил навстречу русским полкам. По дороге к русскому лагерю Алтунопа со своими воинами натолкнулся на разведку русских («сторожу») и был полностью уничтожен (Повесть ..., 1950: 184).

Вслед за тем 3 апреля 1103 г. на реке Сутень столкнулись главные силы русского и половецкого войска. Яркое описание этого одного из крупнейших сражений в древнерусской истории оставил летописец: «по-идоша полкове аки борове и не бъ презръти ихъ: и Русь поидоша противу имъ. И Богъ великый вложи ужасть велику в половцъ, и страх нападе на ня и трепетъ от лица русскых вой и дрђмаху сами, и конем ихъ не бъ спьха в ногах. Наши (т. е. русские. - A. И.) же с весельем на коньх и пьши поидоша к ним. Половци же, видьвше устремленье руское на ся, не доступивше побъгоша пред русскими полки» (Повесть ..., 1950: 184). Обращает на себя внимание отмеченная источником разница в боеспособности русского и половецкого войска. В то время как русские атаковали половцев с «весельем», их противники, наоборот, «дрђмаху» - то есть были медлительны и шли в бой с большой неохотой. Причина этого, по словам летописца, заключалась в том, что коням половцев «не бъ спђха в ногах», то есть они не могли развить необходимую скорость для атаки. Последнее было вызвано тем, что за зиму половецкие кони сильно отощали в результате бескормицы и потому с трудом могли нести на себе вооруженного всадника. Русским ратникам, привыкшим к исключительной подвижности легкой половецкой конницы на поле боя, видевшим, как теперь она медленно с трудом двигается среди снегов, действительно могло показаться, что половецкие всадники шли в атаку спящими.

Таким образом, расчет русских князей, построенный на том, что зимой половецкие орды были предельно ослаблены холодами и падежом скота, и их легче было разгромить, полностью оправдался. Характерно, что свою неспособность к сражению уже в первые минуты боя поняли и сами половцы, которые не доходя до боевых порядков русского войска, 
обратились в бегство, и победителям оставалось лишь организовать преследование разбитого и полностью деморализованного врага.

Разгром половцев был полным. По данным русских источников в битве было убито 20 половецких ханов, в том числе глава лукоморских половцев хан Урусоба и 7 других самых влиятельных вождей, которые называются в летописи поименно: Кчия, Арсланопа, Китанопа, Куман, Асупа, Курток, Ченегрепа, Сурьбарь ${ }^{1}$. Половецкий хан Бельдюз попал в плен, но русские князья Мономах и Святополк отвергли его предложение заплатить за свое освобождение большой выкуп и приказали его казнить. Захватив огромную добычу, состоявшую из скота, пленных и разнообразного имущества кочевников, русское войско с победой повернуло обратно на Русь (Повесть ..., 1950: 184).

Несмотря на то, что летописный рассказ о походе 1103 г. довольно подробен, некоторые его аспекты вызывают много неясного. Не совсем понятны причины этого похода. Последние в литературе обычно связываются с невиданным по своим масштабам натиском половцев на русские земли в 1092-1096 гг. (Плетнева, 1990: 53-54). В течении этих пяти неполных лет кочевники шесть раз вторгались в русские земли, причем их осаде подверглись даже такие крупнейшие политические центры Руси как Киев и Переяславль - столицы двух южнорусских княжеств. Русским князьям удалось отразить это нашествие лишь с большим трудом. Летом 1096 г. объединенные полки переяславского князя Владимира Мономаха и Святополка Изяславича Киевского разгромили в битве под Переяславлем орду одного из самых могущественных половецких ханов Тугоркана. Половецкий хан и его сын погибли в битве (Повесть ..., 1950: 151). Вызванное природными катаклизмами, связанными с многолетней засухой и нашествием саранчи, и потому во многом вынужденное вторжение кочевников в рус-ские земли, в конечном итоге истощило силы половецких орд. Их набеги на Русь надолго прекратились. Поэтому, опасность ее землям со стороны кочевников в это время не только не возрастала, но и, наоборот, неуклонно снижалась.

Можно считать, что, несмотря на затишье в русско-половецких отношениях, угроза русским землям со стороны степи в целом продолжала сохраняться. Например, половцы, понеся в предшествовавших сражениях большие потери, могли временно отказаться от набегов и выжидали, когда в их кочевьях подрастет молодое поколение воинов, чтобы начать новую войну. Однако реальных предпосылок к очередному натиску на

${ }^{1}$ Судя по тому, что объединение кочевников из нескольких близкородственных семей - кошей, в степях обычно называли «оба», «епа», «оба» и прибавляли к имени его главы, погибшие половецкие ханы: Урусоба, Алтунопа, Арсланопа, Китанопа, были родовыми старшинами. Несколько родов составляли более крупное формирование - орду. 
Русь у половцев все же было немного.

На рубеже XI-XII вв. каких-либо крупных объединений днепровских половцев, способных возглавить новое вторжение в русские земли, уже не существовало. Орда Тугоркана была разбита еще в 1096 г. под Переяславлем, и после его смерти созданное им в левобережье Днепра крупное, но довольно рыхлое объединение кочевников распалось. Ряд историков считают, что после смерти Тугоркана новым главой левобережных орд был избран хан Боняк - глава половцев, кочевавших в правобережье Днепра, который объединил в своих руках обе половецкие группировки (Плетнева, 1975: 274). Тем самым угроза Руси вновь выросла. Однако, если бы эта опасность реально существовала, поход Мономаха и Святополка в 1103 г. был бы направлен не против относительно слабой орды лукоморских половцев, а против этого нового опасного объединения хана Боняка (Сухарев, 1997: 18). Отсутствие в источниках упоминаний о половецком хане Боняке вплоть до начала новой русско-половецкой войны 1105 г. позволяет считать, что после неудачного вторжения половцев на Русь в 1096г. наравне с группировкой Тугоркана распалось и само объединение правобережных половцев во главе с Боняком. По крайней мере, в начале XII в. какой-либо опасности для Руси оно уже не представляло (там же).

С распадом крупных, но относительно рыхлых политических организаций половцев (союзов орд), оставшиеся половецкие юрты, видимо, вынуждены были отказаться от дальнейших набегов на Русь. Свое основное внимание половцы с этого времени сосредотачивают на другом традиционном для них направлении внешней политики - борьбе против Венгрии и Византии (Рыбаков, 1963: 105) ${ }^{1}$ на Балканах, что во многом было связано с дальнейшим процессом расселения их орд в днестро-карпатских землях. В этих условиях половцам было не только выгодно нормализовать свои отношения с Русью, но просто необходимо, так как это позволяло им не отвлекать военные силы для защиты своих кочевий, расположенных в непосредственной близости от русских границ. Восстановление мирных отношений между половцами и русскими князьями было достигнуто в 1101 г. заключением мирного договора в местечке Саков. В отличие от договоренностей, заключенных половцами с Русью в предшествующее время, на этот раз мир был заключен не от лица какой-либо одной половецкой орды, как обычно, а «от всьх князий» (Повесть ..., 1950: 182), то есть всей Половецкой земли. Это подчеркивает важность, которую придавали

\footnotetext{
${ }^{1}$ Примечательно, что половецкие походы в Грецию и Болгарию не прекратились и после начала серии крупномасштабных походов русских князей в половецкую степь в начале XII в. В 1106 г. половцы были разбиты войсками византийского императора на Дунае (Новгородская первая ... , 1950: 19). Вслед за тем набеги половцев на империю были продолжены в 1114-1115 и 1118 гг. (Князький, 2003: 106).
} 
заключению мира с русскими в степи.

Зачем же в таком случае русским князьям понадобилось нападать на половцев? Чтобы оправдать нарушение Русью перемирия, в литературе высказывается предположение, что половцы первые каким-то образом нарушили его условия (Ляскоронский, 1897: 315-316; Рыбаков, 1962: 47).

Тем самым поход 1103 г. мог представлять собой вполне закономерную реакцию на возобновление кочевниками враждебных действий в отношении русских земель. Однако эта версия не находит подтверждения в источниках. В период с 1097 по 1103 гг. неизвестны какие-либо половецкие набеги на Русь. Если бы такой набег был совершен, вряд ли летописец, и так враждебно относившийся к половцам, «забыл» о нем упомянуть. Выходит, что русская сторона первой нарушила мир с половцами, причем нарушение такого мира должно было быть выгодно русским князьям.

Еще больше запутывает выяснение причин похода 1103 г. то, что его результаты фактически никак не были использованы русскими князьями в последующее время. Вместо того, чтобы продолжить нажим на уцелевшие после разгрома юрты половцев, в следующем 1104 г., по инициативе Владимира Мономаха, южнорусские князья направили свои войска не в степь, а организовали поход на северо-запад, против Полоцкого княжества (Повесть ..., 1950: 185). Правда, сами Мономах и Святополк в поход не пошли, ограничившись посылкой своих младших сыновей и воевод. Дружины союзников захватили в плен одного из полоцких князей Давыда Всеславича и осадили Минск. Однако сам город им взять не удалось, и вскоре они вынуждены были отступить. Усобица закончилась, по меткому выражению летописца, тем, что южнорусские князья «не успьша ничто же» (там же), то есть не добились поставленных целей.

Тем не менее, полоцкая война не только отвлекла значительные военные силы пограничных со степью русских княжеств на север, но и, главное, дала половцам возможность оправиться от недавнего поражения, собраться с силами и уже в следующем году перехватить инициативу в войне с Русью. Прямым результатом отказа Руси от продолжения натиска в степь было усиление среди раздробленных до этого половцев объединительных тенденций. В 1106 г. половецкий хан Боняк возобновил опустошительные набеги на южнорусское пограничье (там же: 186). В следующем 1107 г. произошло объединение крыла западно-половецких орд во главе с Боняком с группировкой восточных орд половцев, кочевавших в Подонье и на Северском Донце, которые со времен нашествия Шарукана в 1068 г. не принимали активного участия в войнах с Русью (Плетнева, 1990: 96). Таким образом, результаты победы на Сутени оказались полностью утрачены русскими князьями всего через год после похода Мономаха. Что заставило русских князей в самый решающий момент войны со 
степью отказаться от продолжения борьбы с половцами и сосредоточить свое основное внимание на решении внутренних проблем, если половецкая угроза югу Руси после похода 1103 г. резко усилилась?

Понять причины этого похода, очевидно, можно лишь учитывая внутриполитическую обстановку, сложившуюся на Руси в начале XII в. Любопытные результаты в этом отношении дает изучение состава участников похода 1103 г. Как мы знаем, в походе приняли участие семь русских князей. Двое из них: Святослав Изяславич Киевский и Владимир Всеволодович Мономах Переяславский - принадлежали к одним из самых влиятельных и могущественных русских правителей; именно их летописец называет организаторами похода против половцев. Возглавляемые ими многочисленные дружины киевлян и переяславцев составляли костяк выступившего в степь объединенного русского войска. Многочисленную рать в походе возглавлял также черниговский князь Давыд Святославич. По своему статусу он был третьим в иерархии русских князей. Однако сам по себе он как правитель ничего не представлял. Давид был возведен на черниговский стол в 1097 г в результате длительной борьбы Святополка и Мономаха против захватившего Чернигов младшего брата Давыда Олега Святославича. Олег был враждебно настроен по отношению к южнорусским князьям и выступал за проведение независимой политики Черниговского княжества. Разгромив последнего, Мономах и Святополк поспешили назначить черниговским князем более сговорчивого брата Олега Давыда, сидевшего до этого в Смоленске. Не блиставший никакими талантами, находившийся в полной политической зависимости от киевского и переяславского князей, Давыд фактически был марионеткой в их руках. Самостоятельной роли в войне с половцами он не играл. Поэтому, хотя формально черниговский князь и входил в когорту самых влиятельных русских князей, считать его таковым можно лишь с большой оговоркой.

Остальные четверо участников похода фигуры малозначительные. Один из них - смоленский князь Ярополк Владимирович, хотя и был правителем богатого и многолюдного смоленского удела, княжил в нем не самостоятельно, а от лица своего отца Владимира Мономаха. Среди русских князей, принявших участие в походе на половцев, летописец называет его последним, что само по себе свидетельствует о незначительности его положения.

Более значительное положение занимал другой участник похода полоцкий князь Давыд Всеславич. Давыд был сыном знаменитого Всеслава Брячиславича (Алексеев, 1966: 252-253), недолго побывавшего в дни Шаруканова нашествия в 1068 г. киевским князем. После смерти отца, Давыд вместе со своими братьями разделили между собой его обширные владения. Как старший среди братьев, Давыд получил удел в стольном 
Полоцке, что формально давало ему повод считать себя главой Полоцкого княжества. Однако его братья, владевшие двумя другими полоцкими уделами, отказывались признавать над собой его власть. Не имея возможности подчинить последних, Давыд вынужден был вступить в союз с южнорусскими князьями Святополком и Владимиром Мономахом, которые, очевидно, обещали оказать ему свою помощь в борьбе с братьями в обмен на участие в походе против половцев.

Двое других участников похода: племянник Святополка Киевского Вячеслав Ярополкович и Мстислав Игоревич, племянник дорогобужского князя Давыда Игоревича, были князьями-изгоями ${ }^{1}$. Какими-либо уделами в русских землях они не владели. Результат привлечения к походу на половцев князей-изгоев, с военной точки зрения, был ничтожен. Изгои не имели уделов, следовательно, не распо-лагали крупными военными дружинами. Присоединившись к русскому войску, они едва ли могли привести с собой больше нескольких десятков воинов. По своему статусу изгои занимали самую низшую ступень иерархической лестницы сильно разросшегося к началу XII в. рода Рюриковичей. Участие их в походе мало, что давало Ярославичам в плане престижа.

Тем не менее, участие в походе князей-изгоев, вероятно, все же преследовало определенные цели. Дело в том, что в политическом отношении князья-изгои, даже лишенные уделов, не были полностью бесправны. Они оставались представителями правившей династии Рюриковичей и как следствие этого - сохраняли, хотя во многом и номинально, право на долю в управлении Русской землей, считавшейся общеродовой собственностью всех Рюриковичей. Поэтому изгои постоянно требовали себе уделы и готовы были отстаивать свои претензии силой оружия. Все это приводило к постоянным конфликтам изгоев с их дядьями, представителями старших ветвей Рюриковичей, стремившихся по возможности отстранить князей-изгоев от управления страной. Особенно ожесточенный характер столкновения между дядьями и племянниками принимают во второй половине XI в., когда изгои становятся главной движущей силой всех без исключения удельных усобиц между Рюриковичами.

Борьба князей-изгоев с сыновьями старших Ярославичей к концу XI в. завершилась крупной победой изгоев. Сразу трем родам изгоев удалось добиться возвращения (в основном, частично) своих родовых владений. Так, Ростиславичи, потомки старшего внука киевского князя Ярослава Мудрого Ростислава Владимировича, сели князьями в Галицкой

${ }^{1}$ На это, в частности, обратил внимание выдающийся дореволюционный историк С. М. Соловьев, который однако никак не прокомментировал эту любопытную деталь (Соловьев, 1988: 384-385). 
земле ${ }^{1}$; Игоревичи, дети одного из младших сыновей Ярослава Игоря во Владимире-Волынском (Повесть ..., 1950: 135); Святославичи, сыновья черниговского князя Святослава Ярославича - в Чернигове (там же: 148). Тем не менее, само изгойство не было изжито, противоречия между дядьями и племянниками продолжали сохраняться. Состоявшийся в ноябре 1097 г. в Любече первый в истории общекняжеский съезд был призван урегулировать существовавшие между князьями территориальные противоречия. Чтобы прекратить истощавшие Русь усобицы, сыновья старших Ярославичей заключили между собой договор, положив в основу дальнейших междукняжеских отношений принцип: «кождо да держить отчину свою» (там же: 170), то есть сохранение за каждым из них земель, удерживаемых на момент заключения договора (История ..., 1996: 172). В случае несоблюдения кем-либо из князей установленного порядка другие участники съезда обязывались совместными силами выступить против стороны, нарушившей договор (Повесть ..., 1950: 171).

Любечские договоренности внесли определенную стабильность в междукняжеские отношения. Однако решения съезда фактически никак не учитывали интересы многочисленных князей-изгоев, из которых никто даже не был приглашен к участию в нем. Вместе с тем, эти решения теперь значительно осложняли возможность возвращения изгоями родовых земель, так как, по договору, в случае начала ими вооруженной борьбы против одного из князей, другие князья - участники съезда должны были оказывать помощь подвергшемуся такому нападению. Тем самым, Любечский съезд, направленный, с одной стороны, на прекращение усобиц среди правивших князей, другой своей стороной был обращен прямо

\footnotetext{
${ }^{1}$ Время и обстоятельства получения Ростиславичами владений в Галицкой земле не совсем понятны. Высказывалось мнение о том, что Теребовль и Перемышль в качестве удела получил отец Ростиславичей Ростислав Владимирович, который ушел отсюда в 1064 г. править в Тмутаракань. Считать так позволяет то обстоятельство, что Ростислав не мог захватить сильное в военном отношении Тмутараканское княжество, не имея значительной экономической и людской базы на Руси. Такой базой, по-видимому, и была Галичина, очевидно, переданная Ростиславу его дядьями при разделе Древнерусского государства в 1054 г. После смерти последнего в Тмутаракани его семья возвратилась в свое галицкое владение, закрепившееся за Ростиславичами еще в период правления в нем Ростислава. Другие историки с этим не согласны и отодвигают закре-пление Галицких земель за Ростиславичами не ранее начала княжения в Киеве Всево-лода Ярославича (1076 г.). Однако эта точка зрения может быть оспорена известием В. Н. Татищева об участии Ростиславичей в 1077 г. в усобице между киевским князем Всеволодом Ярославичем и его братом Изяславом на стороне последнего. Вторгшийся со стороны Польши на Волынь Изяслав заключил союз с Ростиславичами, правившими в пограничных землях, и получил от них военную помощь для дальнейшего похода на Киев. Получи братья свои уделы от Всеволода, от них следовало бы ожидать большей стойкости в защите действующего киевского князя. Переход Ростиславичей в самом начале усобицы на сторону Изяслава позволяет полагать, что свои владения они, скорее всего, получили от него в его бытность киевским князем, и поэтому считали себя обязанными помогать ему в борьбе за возвращение киевского стола. Образование Теребовльского и Перемышльского княжеств, очевидно, следует относить ко времени не позже 1073 г., когда Изяслав был изгнан из Киева своими братьями Святославом и Всеволодом Ярославичами.
} 
или косвенно против многочисленных князей-изгоев. Все это не могло не вызвать острого недовольства изгоев новой политической ситуацией, которая сложилась после Любеча.

Мир, установленный между князьями на съезде в Любече, продержался недолго. Не успели его участники разъехаться по домам, как Святополк Киевский и Давыд Игоревич Волынский схватили теребовльского князя Василька Володаревича, одного из участников съезда в Любече, и ослепили его (там же: 173). В начавшейся вслед за тем усобице, принявшей общерусский характер, Давыд был разбит коалицией южнорусских князей во главе с Владимиром Мономахом, выступившей в защиту любечских договоренностей, а Святополк перешел на ее сторону и даже принял активное участие в войне против своего недавнего союзника (там же: 175). По окончании усобицы победители провели новое перераспределение княжеских столов. Давыд был лишен княжеского стола во Владимиро-Волынском и переведен на княжение в Дорогобуж. Волынь, являвшаяся его прежней вотчиной, отошла в руки киевского князя Святополка Изяславича (там же: 180), а последний отказался от претензий на Новгород, которым владел Влади-мир Мономах (Инков, 2007: 64).

Волынская усобица 1096-1101 гг. оказала чрезвычайно важное влияние на политическую ситуацию во всех русских княжествах. Она завершилась крупной победой двух наиболее влиятельных князей - Святополка Киевского и Владимира Мономаха Переяславского, которые значительно увеличили свои владения за счет присоединения удела Давыда Игоревича и нового перераспределения княжеских столов. Неизбежным результатом этого стало нарушение хрупкого равновесия сил, сложившегося в междукняжеских отношениях после Любечского съезда. Теперь под угрозой экспансии Киева и Переяславля оказались другие, более мелкие русские княжества - Теребовльское и Перемышльское, где правили Ростиславичи, права которых на их владения были им прежде гарантированы любечскими договоренностями (Повесть ..., 1950: 178). Кроме того, ряд влиятельных русских князей, в первую очередь владельцы третьего по значимости удела на Руси - Черниговского княжества Ольговичи вообще не получили в ходе волынской усобицы никаких территориальных приобретений ${ }^{1}$, что также не могло не вызвать их недовольства. Итогом всего этого стал постепенный развал союза русских князей, сложившегося в ходе Любечского съезда.

${ }^{1}$ Об обострении отношений между Ольговичами и Владимиром Мономахом после Любечского съезда позволяют судить в основном косвенные данные. Среди них восстановление в 1099 г. переяславским князем разоренной половцами крепости Городец на р. Остер. Эта крепость была стратегически удобным плацдармом как для наступления на Чернигов, так и для обороны Переяславля с северо-востока. О восстановлении Городца Владимиром Мономахом в этом году сообщает только Н. В. Татищев (Татищев, 2003: 134). 
Собравшийся в июне 1100 г. новый княжеский съезд в городке Витичев, недалеко от Киева, на первый взгляд, вновь продемонстрировал единство русских князей. Принявшие в нем участие князья Святополк, Владимир Мономах, черниговские Давыд и Олег Святославичи и Давыд Игоревич, все прежние участники съезда в Любече, подтвердили принятые раннее договоренности и провели новое перераспределение уделов, по которому потерпевший в ходе волынской усобицы поражение Давыд Игоревич был лишен стола во Владимире-Волынском, а его земли отданы киевскому князю Святополку Изяславичу. Хотя летописец стремится показать единодушие съехавшихся на съезд русских князей и ничего не говорит о каких-либо противоречиях между ними, скрыть растущее недовольство ряда его участников усилением позиций Святополка Киевского и Владимира Мономаха он все же не смог. Галицкие князья Володарь и Василько Ростиславичи не только не приехали на съезд в Витичев, но и проигнорировали распоряжение его участников передать удел ослепшего Василька киевскому князю Святополку Изяславичу (там же: 181).

Летом следующего 1101 г. русские князья собрались на новый съезд в местечке Золотчи. Основным вопросом съезда был вопрос о заключении мира с половцами, приславшими свое посольство на Русь. Князья решили заключить мир, но объявили половецким послам, что заключат его, только если для переговоров к ним прибудут сами половецкие ханы. Местом встречи русской и половецкой стороны был определен пограничный переяславский городок Саков. Осенью 1101 г. съехавшиеся у его стен русские и половецкие князья заключили между собой мир, скрепив его выдачей друг другу заложников (там же: 182).

Несмотря на это, Саковский мир не остановил подготовки киевским и переяславским князьями похода против половцев (Соловьев, 1988: 384). Зимой 1103 г. в Долобске Владимир Мономах и Святополк Изяславич собрали новый княжеский съезд. К этому времени вопрос о походе в степь был уже, видимо, полностью решен. Приехавшим на съезд князьям оставалось лишь обговорить некоторые его детали, которые в основном касались определения сроков его начала. После некоторых препирательств, вызванных в основном нежеланием киевской дружины Святополка выступить в поход против половцев весной под предлогом того, что тот отвлечет от полевых работ смердов, с пламенной речью, ставшей впоследствии знаменитой, к собравшимся обратился Владимир Мономах. Он заявил, что бессмысленно печься о безопасности крестьянского населения, если вторгшиеся половцы легко могут убить не только самих смердов, но и захватить их семьи и имущество. Своими аргументами Мономаху удалось склонить Святополка Киевского на свою сторону, после чего его предложение о необходимости немедленного выступления в поход 
против половцев было принято всеми участниками съезда (Повесть ..., 1950: 183). Вслед за этим Святополк и Владимир направили приглашение к другим князьям, часть из которых согласилась принять участие в походе на половцев.

Княжеские съезды 1097-1103 гг. рисуют картину редкого для того времени единодушия среди участвовавших в них русских князей. Проникнутые болью за Русскую землю, истерзанной усобицами и половецкими набегами, Рюриковичи решают отбросить раздиравшие их противоречия и, объединиться в борьбе с внешней опасностью. Однако эта рисуемая летописцем идиллия не должна обманывать, поскольку мы располагаем фактически только той версией событий, которая сохранилась только в единственном дошедшем до нас источнике - «Повести временных лет». Автор последней был сторонником киевского князя Святополка Изяславича и особенно, переяславского князя Владимира Мономаха, и потому стремился в выгодном свете отразить их действия на страницах своего бессмертного труда.

Ситуация, в которой приходилось действовать киевскому и переяславскому князю, была намного сложней, а зачастую и менее благоприятной для них. Созданный на Любечском съезде союз самых влиятельных русских князей, призванный по замыслу его инициаторов Святополка и Мономаха внести стабилизацию в междукняжеские отношения, был очень непрочным. Сразу же после его окончания он распался (как показали последующие события, временно). Среди его участников образовалось две коалиции, которые в ходе последующей за ослеплением Василька волынской усобицы с оружием в руках выступили друг против друга. После разгрома Давыда Игоревича, союз князей был восстановлен, но не полностью. Из-за попыток киевского и переяславского князей использовать результаты своей победы над Давыдом в личных целях, проведя с этой целью новый передел княжеских столов, его распад вскоре продолжился с новой силой.

Подтверждением тому стало уменьшение представительности княжеских съездов в последующее время. Так, в Любечском съезде в 1097 г. участвовали шесть самых влиятельных русских князей: Святополк Киевский, Владимир Мономах Переяславский, черниговские Давыд и Олег Святославичи, Давыд Игоревич Владимиро-Волынский и Василько Ростиславич Теребовльский, представлявшие наиболее значительные княжества Южной и Юго-Западной Руси. Спустя три года на съезде во Втичеве, князей было уже только пятеро: отсутствовал Василько Ростиславич, который на съезд не приехал или, скорее всего, не был приглашен другими князьями.

На съезд в Золотчи летом 1101 г. из прежних участников княжеских 
собраний приехали уже только четверо: Святополк, Владимир Мономах, Давыд и Олег Святославичи. Василько Ростиславич на съезд вновь не приехал, а Давыд Игоревич, выведенный Святополком и Владимиром Мономахом из состава общекняжеских съездов еще на предыдущем Втическом съезде, не мог принять в нем участие. Тем самым с удалением этих князей, к 1101 г. из состава коалиции южнорусских княжеств, созданной на Любечском съезде Святополком и Мономахом, фактически вышла вся Юго-Западная Русь. Правда, на съезде в Золотчи к союзникам присоединился новый участник - рязанский князь Ярослав Святославич (там же), представлявший на нем северо-восточные русские земли. Однако вхождение в княжескую коалицию небогатого людскими резервами Рязанского княжества не могло компенсировать выхода из нее богатых юго-западных земель.

На этом развал «общерусской» коалиции не остановился. В собравшемся зимой 1103 г. новом княжеском съезде в Долобске, по данным летописца, участвовали всего два князя: Святополк и Мономах. Позднее к собранному ими войску для похода против половцев присоединились черниговский князь Давыд Святославич и полоцкий князь Давыд Всеславич, находившиеся с киевским и переяславским князьями в союзнических отношениях. Но зато два других участника съезда в Золотчи - братья Давыда Святославича Олег (участник также съезда в Любече) и Ярослав Святославичи - в поход не пошли, причем Олег прямо отказался, сославшись на болезнь (там же). Больше Олег Святославич в общерусских акциях, за исключением тех из них, которые непосредственно касались вопросов обороны его земель ${ }^{1}$, не участвовал. Таким образом, на протяжении 1097-1103 гг. общерусская коалиция, сложившаяся в Любече, уменьшилась ровно наполовину: к началу 1103 г. из ее состава вышли большинство князей Юго-Западной Руси и часть черниговских князей, которые заняли (как, например, Ростиславичи) по отношению к Святополку и Мономаху враждебную позицию2, или (как Олег Святославич) придерживались вооруженного нейтралитета.

Угроза власти Святополка и Мономаха в это время росла и на под-

\footnotetext{
${ }^{1}$ В 1107 г. Олег Святославич принял участие вместе с другими русскими князьями в отражении вторжения крупных половецких сил во главе с ханами Боняком и Шаруканом Старым в Левобережную Русь (Повесть ..., 1950: 186). Причиной его участия в этом походе, очевидно, было то, что половцы угрожали его владениям, располагавшимся на территории возникшего позже на востоке Черниговского удела Новгород-Северского княжества.

2 В 1097-1099 гг. Ростиславичи открыто воевали против киевского князя Святополка и поддерживавших его черниговских князей. В 1100 г., как уже отмечалось, они отвергли требование участников съезда в Уветичах передать киевскому князю Теребовль. Враждебное отношение Ростиславичей к южным князьям сохранялось во многом и позднее. Так, например, в 1123 г. они поддержали своими дружинами мятеж волынского князя Ярослава Святополковича против киевского князя Владимира Мономаха (Полное ..., 2001: 287).
} 
контрольных им землях. В 1101 и в 1102 гг. в волынской земле, подчинявшейся Святополку, дважды вспыхивал мятеж, возглавленный его племянником Ярославом Ярополковичем, который лишь с трудом был подавлен киевским князем (там же: 182). Опасность для князей-соправителей на Волыни, очевидно, представляли также действия князя-изгоя Мстислава Давыдовича, племянника разгромленного ими Давыда Игоревича, который, по примеру своего дяди, в прошлом известного пирата, занимался грабежами на Черном море (там же: 181). Учитывая, что в 1084 г. Давыду удалось именно этим способом заставить киевского князя Всеволода Ярославича выделить ему удел на Руси (там же: 135), можно было ожидать, что Мстислав одними грабежами купеческих караванов ограничиваться не собирался.

Рост напряженности в междукняжеских отношениях, обозначившийся в начале XII в., требовал от Святополка и Мономаха принятия неотложных мер по изменению ситуации в более благоприятную для себя сторону. Разрядить обстановку оба князя могли либо согласившись выделить изгоям уделы и поделиться своими владениями с другим князьям, либо попытавшись вовлечь последних в том числе и враждебных к ним князей, к решению крупных внешнеполитических задач. На первое Святополк и Мономах по вполне понятным причинам никогда бы не согласились. Оставалось второе. И здесь, война с половцами была как никогда выгодна. Во-первых, идея такой войны была крайне популярна среди населения всех без исключения южнорусских княжеств. Во-вторых, походы в степь укрепляли авторитет его организаторов. В-третьих, привлечение к ним большого количества изгоев и мелких князей позволяло отвлечь эту беспокойную вольницу от усобиц. Предстоявшая война против половцев несла определенную выгоду и для самих изгоям, открывая для последних возможность материального обогащения за счет захвата военной добычи.

На то, что поход 1103 г. преследовал не только военно-политические, но и во многом грабительские цели, намекает летописец. Свой рассказ о победе над половцами он завершает подробным перечислением различной добычи, захваченной русским войском: «взяша бо тогда скоты, и овць, и конъ, и вельблуды, и вежъ с добыткомъ и с челядью... и с полоном великым...» (там же: 185). Следует отметить, что это первое подробное перечисление захваченной русским войском добычи, встречающееся в летописи.

Таким образом, поход против половцев был весьма пестрым по своему составу. Помимо двух самых влиятельных и могущественных русских князей Святополка Киевского и Владимира Мономаха, участие в нем приняли зависимые от них князья и правители мелких уделов. При этом треть всех участников составляли князя-изгои!

Поход 1103 г. показал, что уже на ранней стадии борьбы с половца- 
ми степные походы русских князей имели, по крайней мере, два вектора направления: с одной стороны, они были направлены на ослабление, а отчасти и ликвидацию половецкой угрозы русским землям, с другой же были обращены как бы внутрь Руси, подчинены решению острых внутриполитических задач, связанных с укреплением единства страны, стабилизацией междукняжеских отношений, прекращением удельных усобиц. Последующие походы в степь привели к еще большему сращиванию этих двух направлений.

\section{СПИСОК ЛИТЕРАТУРЫ}

Алексеев, Л. В. (1966) Полоцкая земля (Очерки истории Белоруссии в XI-XIII вв.). М. : Наука. 296 с.

Гумилев, Л. Н. (1994) В поисках вымышленного царства. СПб. : Абрис. 383 c.

Инков, А. А. (2007) Древняя Русь и кочевники южнорусских степей в X-XIII вв. Русь и половцы. М. : Изд-во МосГУ. 142с .

История России с древнейших времен до конца XVII века (1996) / А. П. Новосельцев, А. Н. Сахаров, В. И. Буганов, В. Д. Назаров; отв. редактор А. Н. Сахаров, А. П. Новосельцев. М. : АСТ-ЛТД. 576 с.

Князький, И. О. (2003) Византия и кочевники южнорусских степей. Спб.: Алетейя. 181 с.

Кудряшов, К. В. (1948) Половецкая степь: Очерки исторической географии. М. : Географгиз. 162 с.

Ляскоронский, В. Г. (1897) История Переяславской земли с древнейших времен до половины XIII столетия. Киев : Тип. И. И. Чоколова. 510 с.

Мургулия, М. П., Шушарин, В. П. (1998) Половцы, Грузия, Русь и Венгрия в XII-XIII вв. М. : Институт славяноведения и балканистики РАН. 334 с.

Новгородская первая летопись старшего и младшего изводов (1950). М. ; Л. : Изд-во АН СССР.

Перхавко, В. Б., Сухарев, Ю. В. (2006) Воители Руси IX-XIII вв. М. : Вече. 448 c.

Плетнева, С. А. (1975) Половецкая земля // Древнерусские княжества X-XIII вв. М. : Наука. С. 260-301.

Плетнева, С. А. (1990) Половцы. М. : Наука. 208 с.

Плетнева, С. А. (1992) Половцы и черные клобуки // История Европы : в 8-ми т. М.: Наука. Т. 2. С древнейших времен до наших дней. С. 466-470.

Повесть временных лет (1950) / gод ред. В. П. Адриановой-Перетц. М.; Л. : Изд-во Ан СССР. Ч. І. 405 с.

Полное собрание русских летописей (2001). М. : Языки славянской культуры. Т. ІІ. Ипатьевская летопись. 648 с.

Рыбаков, Б. А. (1962) Обзор общих явлений русской истории IX - сер. 
XIII вв. // Вопросы истории. № 4. С. 34-58.

Рыбаков, Б. А. (1963) Древняя Русь: Сказания. Былины. Летописи. М. : Изд-во АН СССР. 361с.

Соловьев, С. М. (1988) Сочинения : в 18 кн. М. : Мысль. Кн. 1. История России с древнейших времен. Т. I-II. 797 с.

Сухарев, Ю. В. (1997) Донской поход Мономаха // Родина. № 3-4. С. 28-33.

Татищев, В. Н. (2003) История Российская : в 3-х т. М. : ООО «Издательство АСТ» Т. II. 732 с.

Дата поступления: 15.06.2016 г.

Инков Александр Александрович - кандидат исторических наук, доцент, доцент кафедры истории Московского гуманитарного университета. Адрес: 111395, Россия, г. Москва, ул. Юности, д. 5. Тел.: +7 (499) 374-5581. Эл. адрес: antigon1922@уandex.ru

Inkov Aleksandr Aleksandrovich, Candidate of History, Associate Professor, Department of History, Moscow University for the Humanities. Postal address: 5 Yunosti, St., 111395 Moscow, Russia. Tel.: +7 (499) 374-5581.E-mail: antigon1922@yandex.ru 